AUTHOR CORRECTION

\title{
Author Correction: Deep learning for automated sleep staging using instantaneous heart rate
}

Niranjan Sridhar (D), Ali Shoeb, Philip Stephens, Alaa Kharbouch, David Ben Shimol, Joshua Burkart, Atiyeh Ghoreyshi and Lance Myers

npj Digital Medicine (2020)3:131 ; https://doi.org/10.1038/s41746-020-00337-9

Correction to: $n p j$ Digital Medicine https://doi.org/10.1038/s41746020-0291-x, published online 20 August 2020

The original version of the published Article contained a typographical error in the spelling of a trademarked name in the Methods. The spelling of ZMachine has been corrected to Zmachine and includes the manufacturer name and location at first mention in the Methods.

The HTML and PDF versions of the Article have been corrected.

Open Access This article is licensed under a Creative Commons Attribution 4.0 International License, which permits use, sharing, adaptation, distribution and reproduction in any medium or format, as long as you give appropriate credit to the original author(s) and the source, provide a link to the Creative Commons license, and indicate if changes were made. The images or other third party material in this article are included in the article's Creative Commons license, unless indicated otherwise in a credit line to the material. If material is not included in the article's Creative Commons license and your intended use is not permitted by statutory regulation or exceeds the permitted use, you will need to obtain permission directly from the copyright holder. To view a copy of this license, visit http://creativecommons. org/licenses/by/4.0/.

(c) The Author(s) 2020 